Bansal Atul,

Associate Professor-Accounting, College of Administrative and Financial Sciences, GULF University, Kingdom of Bahrain.

ORCID: 0000-0002-7083-9413

\title{
ASSESSMENT OF NEWLY IMPLEMENTED VALUE ADDED TAX ON ECONOMIC GROWTH AND DEVELOPMENT OF KINGDOM OF BAHRAIN
}

Value Added Tax (VAT) is a consumption tax is being charged on goods and services. VAT is a major worldwide tax instrument which enhances economic growth. Recently GCC countries has executed VAT and Kingdom of Bahrain also implemented it as on $1^{\text {st }}$ January 2019. The aim was to increase the revenue base of Government and make fund available for developmental purposes that will accelerate economic growth. This research aim is an empirically examination on the contribution of VAT to the growth of economy and identify the reasons of implementing the VAT in the Kingdom of Bahrain and to outline the effects, benefits, and challenges of doing so. This study provides certain considerations to be taken in line of Kingdom of Bahrain's economic environment, these considerations are mainly aimed to define the effects of VAT related SMEs and other business, VAT as a cultural policy tool, and the implications of VAT. As well as defining expected challenges related to levels and rates of VAT compliance, periodical changes in VAT laws, VAT collections and refunds, financial literacy, complexities of VAT legislation, and control over the cost of living. The data of this study was collected from secondary and primary sources from selected SMEs, business, and general public overview of Kingdom of Bahrain. Some findings and suggestions are addressed in the study that may be the prerequisite for banking organizational growth and development.

Keywords: VAT, TAX, GCC, Revenue, Economy

Бансал Атул. Оцінка впливу нещодавно введеного податку на додану вартість на економічне зростання та розвиток Королівства Бахрейн.

Податок на додану вартість (ПДВ) - податок на споживання, щзо входить у иіну товарів та послуг. ПДВ є основним податковим інструментом у світі, який сприяе економічному зростанню. Нещодавно країни РСАДПЗ почали застосовувати ПДВ, зокрема Королівство Бахрейн почало застосовувати його з 1 січня 2019 року. Метою введення ПДВ було збільшити дохідну базу уряду та забезпечити доступність коштів для розвитку країни, що прискорить економічне зростання. Метою дослідження є визначення внеску 
ПДВ у зростання економіки, виявлення причин впровадження ПДВ у Королівстві Бахрейн, окреслення наслідків, переваг та викликів иього кроку для краӥни. Це дослідження містить висновки щодо наслідків впровадження ПДВ для МСП та іншого бізнесу, ролі ПДВ як інструменту культурної політики. Окрім того, розглянуто виклики, пов'язані із рівнем ставки ПДВ, періодичними змінами у законах про ПДВ, зборами та поверненням ПДВ, фінансовою грамотністю населення, складністю законодавства про ПДВ та контролем за витратами на життя. Дослідження містить данні з вторинних та первинних джерел, зокрема МСП, іншого бізнесу та загальний огляд Королівства Бахрейн. Деякі висновки та пропозищї проведеного дослідження можуть бути використані для розвитку підприємств банківського сектору.

Ключові слова: ПДВ, податок, РСАДПЗ, дохід, економіка.

\section{Introduction}

The research discusses about the increase in value added tax in the Kingdom of Bahrain, and it was also mentioned that it will be implemented in the year 2019, January $1^{\text {st }}$. it was the official announcement that was made in order to release the regulation. The Kingdom of Bahrain is considered to be attractive as well as low tax environment, in order to keep the environment for the wider use of developmental reforms. Introduction of the value added tax on the supply of goods and services is framed to be at the rate of 5\% in the previous financial year 2018. Implementation of value added tax for the business procedurals and new taxpayers will have implications in the Bahrain's Kingdom.

\section{Research aim}

The aim of this research study is to investigate and analyse the increasing impact of the value added tax in the Kingdom of Bahrain. It also aims in setting out all the rules and procedures of VAT in order to provide general information. There is no responsibility in order to assume the binding of documents and committing the increase in revenue for any taxpayer.

\section{Research question}

- What are the effects of value added tax in the Kingdom of Bahrain?

- What are the characteristic features of VAT in order to increase the revenue?

- Determine the impact of VAT in order to satisfy the marketers as well as consumers?

- Analyse the perception of retailers, chartered accountants, wholesalers, consumers and tax officials regarding the increase in VAT in The Kingdom of Bahrain?

\section{Research objectives}

- To analyse the effects of value added tax in the Kingdom of Bahrain

- To identify the characteristic feature of value added tax with respect to increase in revenue 
- To determine the impact of value added tax on satisfying the marketers and the consumers

- To analyse the perception of retailers, chartered accountants, wholesalers, consumers and tax officials regarding the increase in VAT in The Kingdom of Bahrain

\section{Problem statements}

Value added tax is the indirect tax, which is imposed on the goods and services. This imposition is operated by the government when budget surplus is taken into consideration, with respect to increase in revenue and it financial budgetary deficit. Value added tax generated revenue in order to evading tax not only on the products but also on the services in order to generate high source of revenue in the business economy. Taxes and duty charges are imposed by the government on the people in order to fulfil the infrastructural demand, technological demand and entrepreneurial demand. The purpose of this study is to set out all the general principles of VAT related to the Kingdom of Bahrain, and also aims in providing all the rules and regulations, which is necessary to determine the supply for VAT. Implementation of value added tax for the business procedurals and new taxpayers will have implications in the Bahrain's Kingdom as stated by (Baunsgaard \& Keen 2010).

\section{Literature review}

VAT preparations are definitive in order to accelerate the business by introducing it with new and big challenges, which are effective for the business from the aspect of non-tax environment. Value added tax impacts in obligating the operations from the standard rate and also makes Bahrain aware of launching new version of value added tax as a guide in order to support the business organisations. VAT is experienced in all the parts of the countries and is also implemented in order to keep track on the laws and regulations that might increase in the future terms.

\section{Effects of value added tax on expats in the country}

According to Mears (2016), the survey conducted regarding the value added tax for the members of GCC in United States of Arab enjoyed the high price levels from extracting oil and delivering it to the international summits. These businesses were rated with low taxations, which was surprising for majority of people and lately it started considering all types of taxes and also provide benefits to the GCC states. There certain international as well as domestic factors that compelled the GCC to reconsider the taxation policies in order to extract energies from the consumption of threat which are increasing on the daily basis. Welfare policies are also absorbing the revenues of GCC; this shows the increase in free trade zones from the ongoing trade in the national level. The first policy that needs to be adopted is direct and indirect tax, which reviews the historical perspective of taxation of all the business in the recent years. Increase in economic globalisation in GCC countries are advised to implement taxation strategies in order to keep the organisation from the emended pressure from the governmental aspects and from financial institutions. 


\section{Consequences of value added tax with respect to inequality}

As opined by Alavuotunki et al. (2017), this research impacts on the introduction the value added tax on the revenues that are generated for the governments by the use of micro data. This introduction leads to affect the conventional county with respect to effective regression analysis and instrumental analyzed variable. Development of tax revenues, which are increasing in the developing industries by building the domestic revenues with efficient capacities and challenges are financially fighting with the poverty. These are unfortunately affecting the economic activities. Involving and introducing the income tax as well as the personal income tax stands out for innovation strategies for majority of the countries in GCC and UAE. All the policies of the value added tax was accompanied with the reduction of all the duties such as the custom duties as well as the excise duties and also including the tariffs as well. Therefore, these policies leads to the expansion of Value added tax by striking all the membership aspects in the developing economy in the world.

\section{Generating revenue from oil and state budget dynamics}

As opined by Kreishan et al. (2018), the research discuses about the long term relationship and the short term relationship among the revenues and expenditures of the government. It also uses the analysis of the time series as well as analysis of the annual data with respect to integrated variables, which results in revealing the all the governmental aspects. It also mentioned that increase in oil with $1 \%$ leads to inducement of governmental expenditures. Moreover, the policymaker of Bahrain focuses on diversifying the governmental revenues from various sectors, especially from the oil market. Adoption of revenue from the state budgeting and oil refining revenue leads in promoting the economic development as well as the social goals of the government towards the development of the educational system, healthcare, economic activities as well as the social activities to improve the well-being of the public with respect to increase in their standard of living.

\section{Policy implication of taxes with respect to outputs}

According Gunter et al. (2019), it was stated that the tax changed its output with respect to non-linear effects that took place with the innovation of the initial taxation policies. This initial role of the taxation policies uses the tax multipliers aspects and the narrative approach in order to identify the tax changes as well as the findings that are related to the theoretical aspect of tax multiplier. Identification of the data sets with respect to novels among 51 countries and identifying the exogenous changes reports about the estimation. Evaluation of the initial tax levels negatively multiplies the highest values and also tends to become zero at the low levels of the initial tax rates. This evidence shows the effect of change in output, which is highly non-linear. These findings have some important implications, which reflect the potential output in order to affect the rate of changes in the tax rates. The research basically focuses on the outputs which results in the non-linear effects, which change 
the output of the relevant policies. It focuses on the relevance of outputs due to the arguments that are mobilizing in provisioning of goods and social aspects in order to bridge the infrastructural gaps.

\section{Mandatory adoption of financial reporting with respect to reducing the income tax revenue}

According to Mao \& Wu (2019), it was stated that it is mandatory for all the business to adopt the international financial reporting standards that is mainly known as the IFRS. This adoption is made mandatory with respect to form a regulatory change in GCC countries. This adoption of the IFRS policy bridges all the financial gaps among the earnings of the accounting department as well as the taxable income, which is highly increasing in the GCC countries. From the research conducted, it was suggested that review on the taxes has low rate of conformity, which is adopted in association to avoid the corporate taxes and collection of revenues from the lower income tax. This study examines the governmental impact that has mandated the adoption of IFRS on the country's revenue through the income tax. The strategy uses various data panels in order to cover the empirical results that lead in decreasing the revenue from the income taxes.

\section{Current issues regarding VAT for employment in Gulf Cooperation Council}

Shayah\& Sun (2019), stated that the study focuses on the current issues that are faced with respect to human capitals in order to achieve the economical development aspect from the oil sectors of GCC. The research also discusses about the demographical factors of the GCC countries in order to notify the issues that are contemporary with respect to employment. They have similar characteristics with regards to demographic and labor forces, which is eventually growing the unemployment population in the faster rate. Low employment on the private sectors and low participation of women's is also spreading unemployment among the citizens of GCC. According to the recent study, it came into consideration that the HR practices in the GCC countries are growing and expanding the business with respect to developing the talent and innovation among the employees. It was also mentioned from the study that $5 \%$ of the value added tax has affected the country of UAE in the financial year of 2018 .

\section{Structural constraints of VAT in Bahrain}

Almajdoub (2018), stated that Bahrain is discovering oil from all the gulf region of Arab, Bahrain was the first country, which started its run regarding the oil reserves in diversifying the economy by expanding all the non-oil industry. Implementation of the economic developmental strategy builds in sustainability, competitiveness and faire acceptance of all the governmental plans, which increases the productivity and capacity of the Bahrain's citizens. With respect to the demographic pressures in the Bahrain's economy, the natural resources buffers to measure the government spending which includes the fuel and all subsidized food with introduction of value added tax 
from the financial year of 2018. These announcement of the introduction of value added tax leads to extract all the costs that are determined for the production of commercial investments. This will boost the economic aspects of Bahrain by investing in the oil sectors with respect to expand the fiscal position, which is blowing the financial sectors. It was also noted that the GCC countries includes GINI index with respect to measure the inequality on the basis of per capita GDP.

\section{Value added tax on corporate governance and inequality}

According to Chan \& Ramly (2018), it was stated that the inequality in the income is one of the growing concern, because it is adversely affecting the stability of the socio economics and also regulates the institutional stability and the economical performances. Despite of reduction in the income inequality, implementation of VAT is still being criticized because of the regressive nature. The effect of VAT is enhancing the income inequality, which is focusing on the moderating role, which generalizes the endogeneity issues and the auto correction issues. The role of VAT reduces the debatable issues which are regressive in nature and also earns huge percentage of income of consumption on the food and services. These services are compared to the individual whose income is higher and also widens the income inequality. Investigating about the impact of VAT develops the income inequality by initializing the role of governance in the country of GCC. The research basically focuses on the value-added system in order to determine the governance factors by improving the link between the VAT and the inequality of income.

\section{Analytical approach on $\mathrm{VAT}$ revenue elasticity}

As opined by Acheson et al. (2018), the analytical approach states the elasticity that is generated from estimating the VAT revenues which underlies the income and expenditures of the regulatory reforms. The VAT revenue generated leads to changes in output of the households, which is steadily increasing in the current economy. Introducing of VAT in the income inequality doubles the result regarding the reduction in elasticity of VAT. It states that higher the income tax rate more is the reduction in the disposable incomes. This research also highlights the importance of tax policies, which are judging the policy makers in order to have a broader knowledge regarding the fiscal crisis with a composition of tax. The elasticity of the VAT revenue is lower than it estimates to be in order to have a greater progress report with respect to income tax system as compared to other countries. Analytical estimation of VAT leads to responsiveness in generating revenues to change the income levy and change in health ley as well. VAT is applied to all the countries in the world in order to share the accounts of the total tax revenue with respect to significant variance.

\section{Structural theory of VAT}

According to Keen \& Lockwood (2010), this theoretical aspect describes about the VAT functions on the In-house basis, in order to prepare for the change with respect to transforming of new projects into structural way. This will lead to wider the business with the help of development and changes that are relevant in engaging the 
process. Implementation of planning, designing and monitoring of VAT within the business function considers all the issues regarding resource constraints in an organisation, availability of the technical expertise with specialised knowledge, designing of process and integration of core business policies, monitoring of risk management and implementation of governance, potential support for the technology is required in order to gather all the data and also processing of complex business functions.

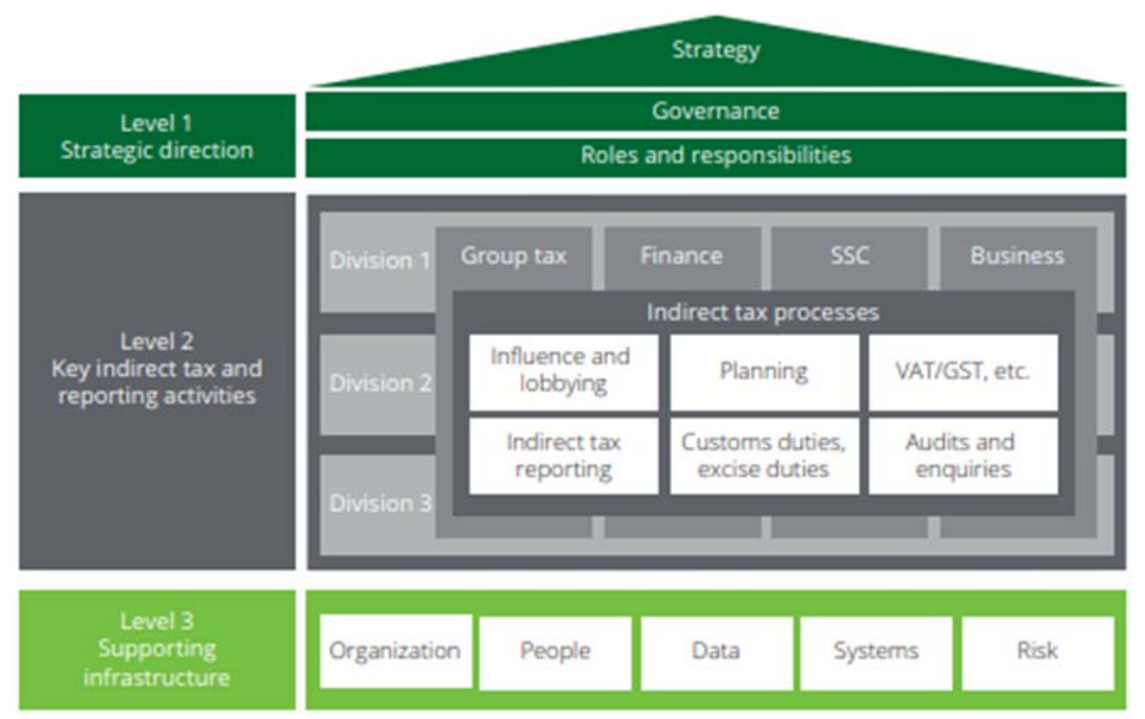

Figure 1. Structure of VAT (Keen \& Lockwood 2010)

The above diagram illustrates about the leading levels of taxation approach in order to functionalise the indirect tax of the business. The types of function and activities that are performed globally in the GCC countries are mentioned within the diagrammatical representation. The first level talks about the strategic direction, which includes the head of value added tax that is applicable to all the members in the senior department of financial institutes. This includes the functional ownership over the governance factors and activities with respect to their roles and responsibility. The second level discusses about key of indirect taxes and its reporting activities with respect to financial team members and the third level describes about supporting the infrastructural aspects which processes all the risk factors and underpins all the operational frameworks that is supported by the in -house VAT.

\section{Research methodology}

According to Mears (2016), this study focuses on the positive research philosophy, and this positivity extracts surveys and statistics, which implies collecting of primary data. This research, studies the non-probability method of quota sampling which leads to extracts convenient data that is involved in this quota sampling. The methodology complies of various scale of measurement for VAT from various financial institutes in order to generate the VAT functions. This dissertation will provide a clear knowledge about the tools and the functions which are utilised in order 
to find out all the revenue aspects that are generated from the financial aspect of value added tax. In order to conduct a research regarding VAT, its effects on the income generation as well as in the income inequality of the individuals in the Kingdom of Bahrain.

\section{Research Philosophy}

Research philosophy will consider the positive characteristics which take the factual knowledge about the VAT from all the financial aspects of the business. This section of research philosophy provides the main idea collection of data through effective methodology and also analyzing the datasets in a proper manner. In order to conduct the research all the four philosophies are represented which deals with positivism, post-positivism, realism as well as interpretive research. Research philosophy is vital in order to outline and analyze the rich essentials of the financial perspectives. This research philosophy not only helps in understanding the dataset of taxation but also helps in assisting and finding the information from all the levels of value added tax as stated by (Baunsgaard \& Keen 2010).

\section{Research approach}

As opined by Chan \& Ramly (2018), the research approach deals with the two approaches in order to analyse the research topic that was based on the taxation policies in Bahrain, to generate the revenues. The two approaches that were used are the deductive research approach and inductive research approach. The deductive research helped in analysing the research with all the relative datasets and with financial documentation. Inductive approach studies the effective way of conducting the research projects.

\section{Research Design}

The research design defines the strategic aspects that were integrated in the research topic in a congruent manner as well as in effective manner. The research design addresses the issues substantially and also addresses the problems in the research study. This research provides structural collection of data with explorative design perspective as well as descriptive design perspective.

\section{Data analysis}

The data analysis is done with the help of primary data and secondary data analysis. The collection of primary data involves information collection from all the sourced data. Majority of the data and information's are collected on the basis of primary data collection, and it also done by utilising the secondary resources such as review, newspapers, books, articles, websites, journals and many more aspects. According to Shayah \& Sun (2019), the utilisation of strategy is done by interviewing through the primary data by providing questionnaires to the respondents. Qualitative and quantitative research strategy is followed in the research topic in order to interview the respondents along with conducting a survey.

This research summarises about the VAT, generated revenue for the kingdom of Bahrain. This generating of revenue affects the economic sectors, which requires 
considerable effort of the people, business, processes, systems as well as the stakeholders for VAT. The research study also highlights about the effective data implementation, which came into force in the month of $1^{\text {st }}$ January, 2019. It also discusses about the scope that will help in revenue generation, and also discusses about the zero rate supplies.

\section{Results and Findings}

The following chapter presents the results or survey which is organized to collect data from the 70 respondents. The questionnaire survey contained 4 demographic and 10 close ended questions that are discussed in the following results and discussion part.

\section{Demographic interpretation}

Table 1

What is your Gender?

\begin{tabular}{|l|l|c|c|c|c|}
\hline & & Frequency & Percent & Valid Percent & $\begin{array}{c}\text { Cumulative } \\
\text { Percent }\end{array}$ \\
\hline Valid & Male & 45 & 61.6 & 64.3 & 64.3 \\
\hline & Female & 25 & 34.2 & 35.7 & 100.0 \\
\hline & Total & 70 & 95.9 & 100.0 & \\
\hline Missing & System & 3 & 4.1 & & \\
\hline Total & \multicolumn{73}{|c|}{} & $\mathbf{1 0 0 . 0}$ & & \\
\hline
\end{tabular}

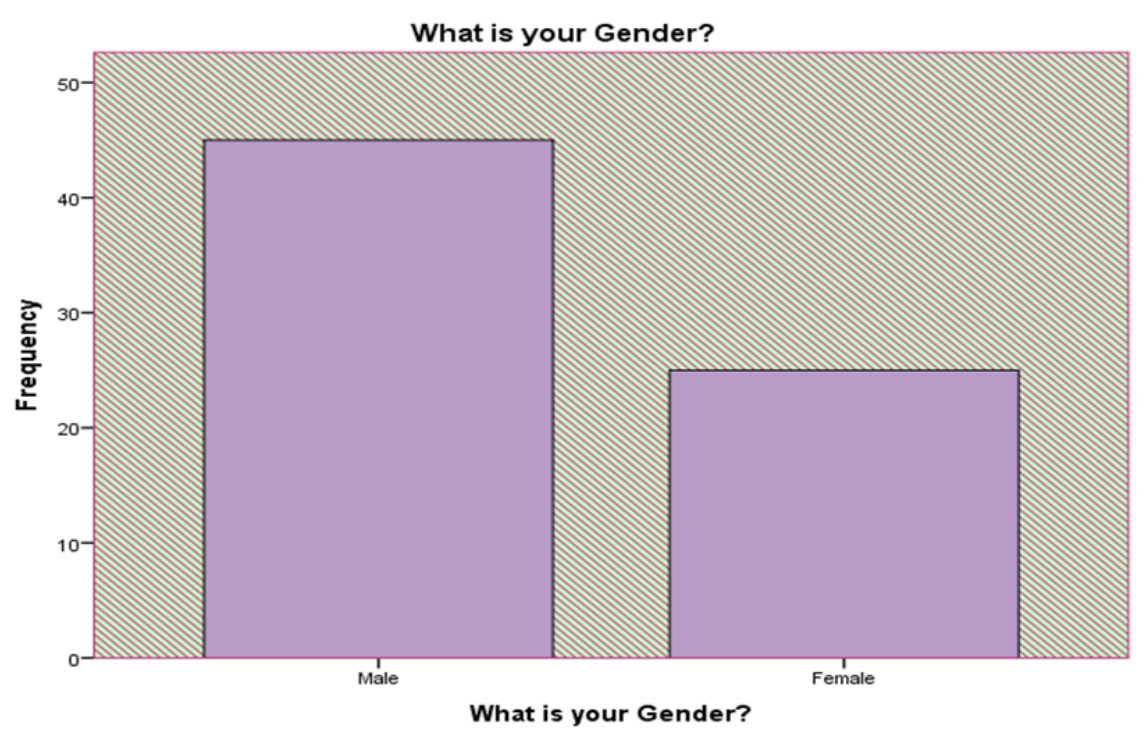

The results presented in the above table and graphs have shown that there were total 70 respondents have contributed in the research in which majority are males that are $61.6 \%$ of the total population and there were 45 males and 25 females' respondents. 
What is your Age?

\begin{tabular}{|c|c|c|c|c|c|}
\hline & Frequency & Percent & Valid Percent & $\begin{array}{c}\text { Cumulative } \\
\text { Percent }\end{array}$ \\
\hline Valid & $21-25$ yrs & 34 & 46.6 & 48.6 & 48.6 \\
\hline & $26-30$ yrs & 16 & 21.9 & 22.9 & 71.4 \\
\hline & $31-40$ yrs & 13 & 17.8 & 18.6 & 90.0 \\
\hline & Above 40 yrs & 7 & 9.6 & 10.0 & 100.0 \\
\hline & Total & 70 & 95.9 & 100.0 & \\
\hline Missing & System & 3 & 4.1 & & \\
\hline Total & & $\mathbf{1 0 0 . 0}$ & & & \\
\hline
\end{tabular}

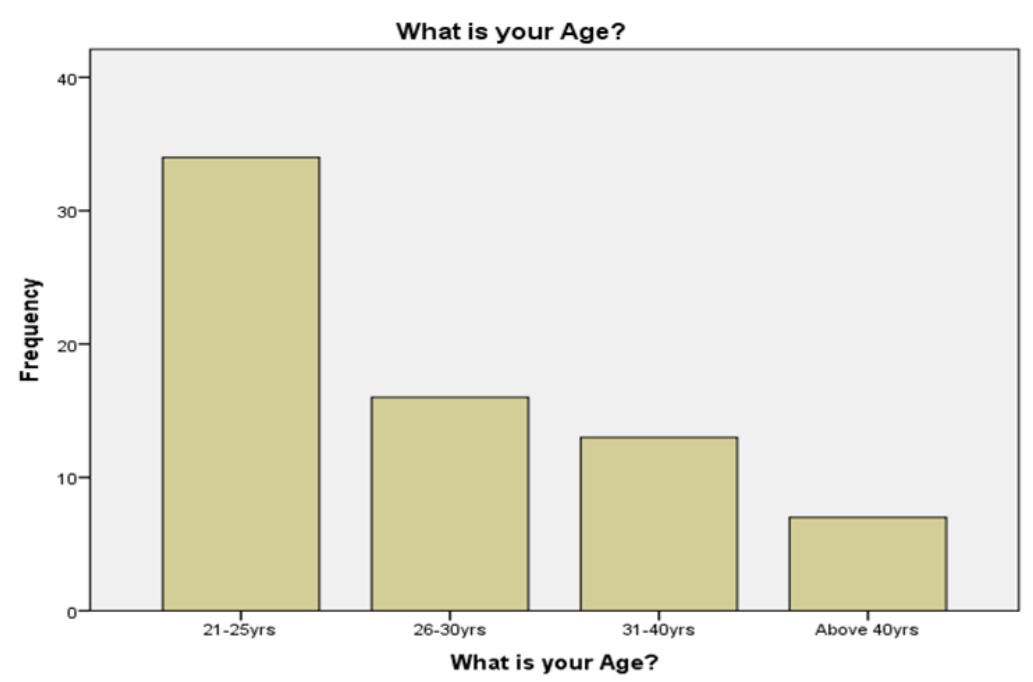

The above graph and table show that majority of the participants belong to the age group of 21-25years as 34 respondents are from the age group 21-25 yrs. The other respondents that have participated in the research belong to 26-30 yrs., $32-40$ yrs. and 7 participants are aged above $40 \mathrm{yrs}$.

Table 3

What is your educational Qualification?

\begin{tabular}{|l|l|c|c|c|c|}
\hline & & Frequency & Percent & Valid Percent & $\begin{array}{c}\text { Cumulative } \\
\text { Percent }\end{array}$ \\
\hline Valid & $\begin{array}{l}\text { Under } \\
\text { graduate }\end{array}$ & 32 & 43.8 & 45.7 & 45.7 \\
\hline & Graduate & 18 & 24.7 & 25.7 & 71.4 \\
\hline & Post Graduate & 13 & 17.8 & 18.6 & 90.0 \\
\hline & Others & 7 & 9.6 & 10.0 & 100.0 \\
\hline & Total & 70 & 95.9 & 100.0 & \\
\hline Missing & System & 3 & 4.1 & & \\
\hline Total & & 73 & 100.0 & & \\
\hline
\end{tabular}




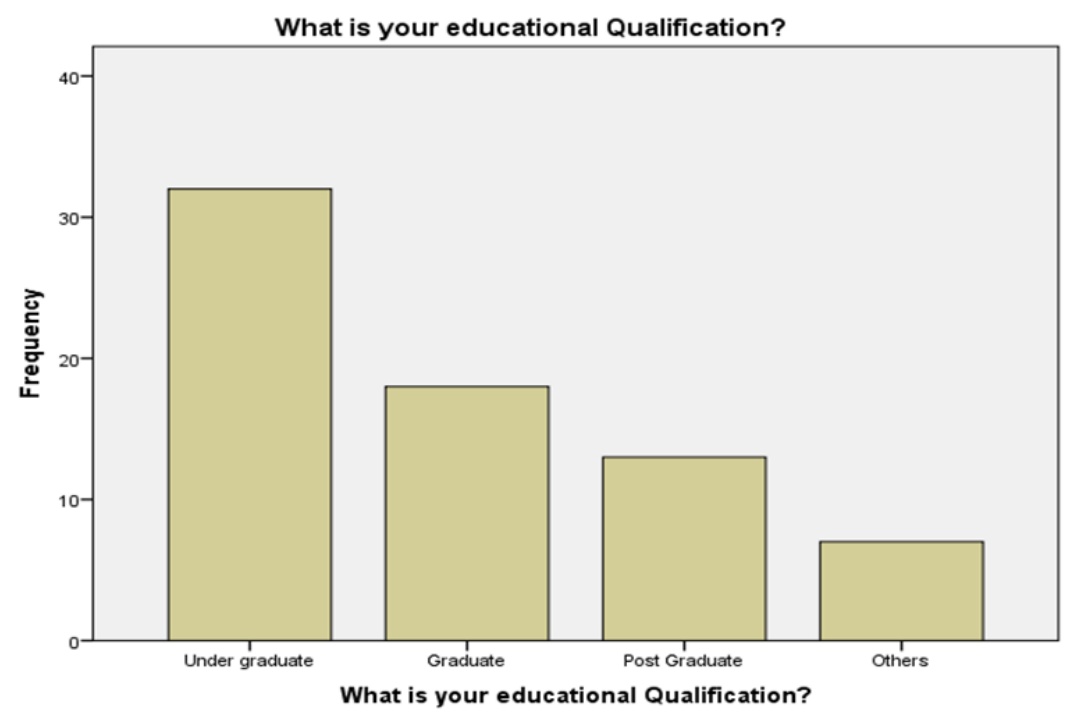

The above table and graph show that from the 70 respondents' majority have qualification under graduate. However, there are also around 18 in respondent who have graduate degree.

Table 4

What is your Profession?

\begin{tabular}{|l|l|c|c|c|c|}
\hline & & Frequency & Percent & Valid Percent & $\begin{array}{c}\text { Cumulative } \\
\text { Percent }\end{array}$ \\
\hline Valid & Student & 28 & 38.4 & 40.0 & 40.0 \\
\hline & Employee & 18 & 24.7 & 25.7 & 65.7 \\
\hline & Unemployed & 15 & 20.5 & 21.4 & 87.1 \\
\hline & $\begin{array}{l}\text { Business } \\
\text { Person }\end{array}$ & 8 & 11.0 & 11.4 & 98.6 \\
\hline & Others & 1 & 1.4 & 1.4 & 100.0 \\
\hline & Total & 70 & 95.9 & 100.0 & \\
\hline Missing & System & 3 & 4.1 & & \\
\hline Total & & $\mathbf{7 3}$ & $\mathbf{1 0 0 . 0}$ & & \\
\hline
\end{tabular}

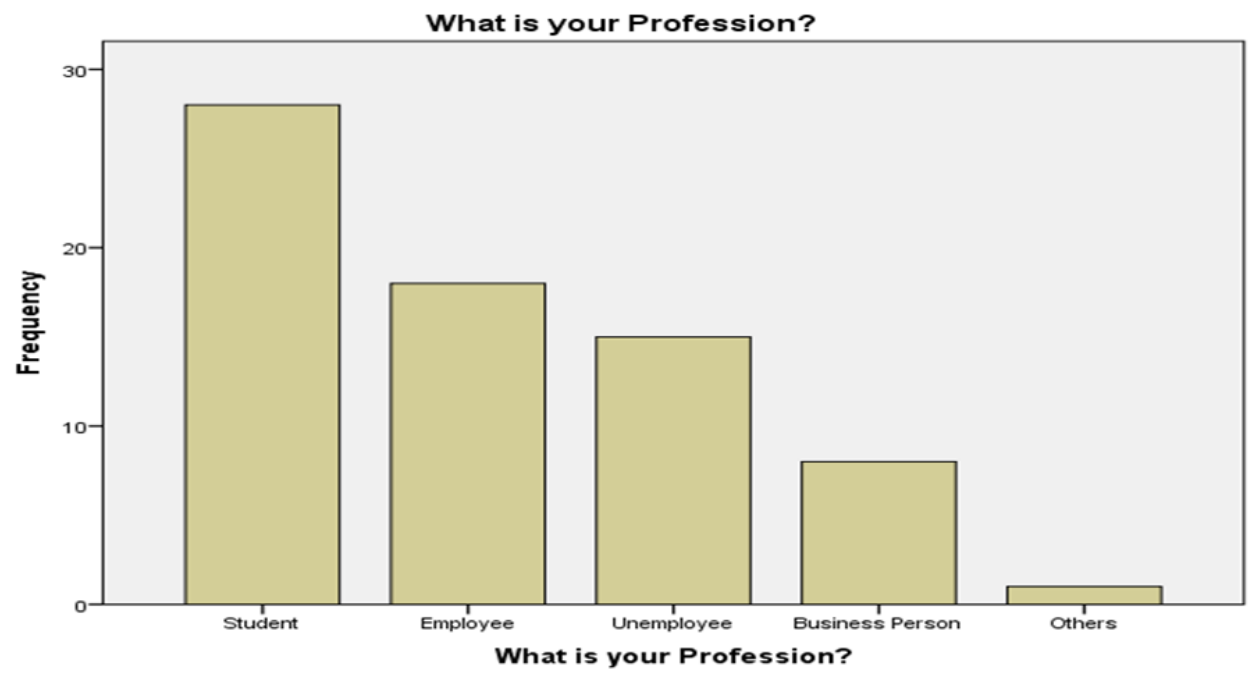


In this demographic question the respondents are asked about their profession. From the research it is found that in the research survey the students are large in number as 28 respondents are student. Following this, the other are employees, business personas and others.

VAT Questionnaire Interpretation

Table 5

The money raised from value added tax would help Bahrain lower the massive BHD 11.5 billion national debt.?

\begin{tabular}{|l|l|c|c|c|c|}
\hline & & Frequency & Percent & Valid Percent & $\begin{array}{c}\text { Cumulative } \\
\text { Percent }\end{array}$ \\
\hline Valid & $\begin{array}{l}\text { Strongly } \\
\text { Disagree }\end{array}$ & 13 & 17.8 & 18.6 & 18.6 \\
\hline & Disagree & 10 & 13.7 & 14.3 & 32.9 \\
\hline & Neutral & 23 & 31.5 & 32.9 & 65.7 \\
\hline & Agree & 20 & 27.4 & 28.6 & 94.3 \\
\hline & $\begin{array}{l}\text { Strongly } \\
\text { Agree }\end{array}$ & 4 & 5.5 & 5.7 & 100.0 \\
\hline & Total & 70 & 95.9 & 100.0 & \\
\hline Missing & System & 3 & 4.1 & & \\
\hline Total & & $\mathbf{7 3}$ & $\mathbf{1 0 0 . 0}$ & & \\
\hline
\end{tabular}

The above table shows the frequency of the Q1 in which it is found that the people has mixed response about the statement that «VAT would help Bahrain to reduce Debt» as 20 respondents believe that VAT implementation strategy would work in reducing and paying back the huge debt.

Table 6

A value added tax would help Bahrain deal with the major economic issues plaguing its economy?

\begin{tabular}{|l|l|c|c|c|c|}
\hline & & Frequency & Percent & Valid Percent & $\begin{array}{c}\text { Cumulative } \\
\text { Percent }\end{array}$ \\
\hline Valid & $\begin{array}{l}\text { Strongly } \\
\text { Disagree }\end{array}$ & 24 & 32.9 & 34.3 & 34.3 \\
\hline & Disagree & 18 & 24.7 & 25.7 & 60.0 \\
\hline & Neutral & 21 & 28.8 & 30.0 & 90.0 \\
\hline & Agree & 6 & 8.2 & 8.6 & 98.6 \\
\hline & $\begin{array}{l}\text { Strongly } \\
\text { Agree }\end{array}$ & 1 & 1.4 & 1.4 & 100.0 \\
\hline & Total & 70 & 95.9 & 100.0 & \\
\hline Missing & System & 3 & 4.1 & & \\
\hline
\end{tabular}


In the response of the survey question about the hope of associated with the VAT to resolve the economic issues, it is found that some respondents do not expect that VAT would be effective in solving economic issues of Bahrain as 24 strongly disagreed about the statement. These results show that people are Bahrain seems not happy with the implementation of VAT.

Table 7

VAT encourages people to save more money to avoid paying taxes?

\begin{tabular}{|l|l|c|c|c|c|}
\hline & & Frequency & Percent & Valid Percent & $\begin{array}{c}\text { Cumulative } \\
\text { Percent }\end{array}$ \\
\hline Valid & $\begin{array}{l}\text { Strongly } \\
\text { Disagree }\end{array}$ & 8 & 11.0 & 11.4 & 11.4 \\
\hline & Disagree & 17 & 23.3 & 24.3 & 35.7 \\
\hline & Neutral & 23 & 31.5 & 32.9 & 68.6 \\
\hline & Agree & 14 & 19.2 & 20.0 & 88.6 \\
\hline & $\begin{array}{l}\text { Strongly } \\
\text { Agree }\end{array}$ & 8 & 11.0 & 11.4 & 100.0 \\
\hline & Total & 70 & 95.9 & 100.0 & \\
\hline Missing & System & 3 & 4.1 & & \\
\hline Total & & 73 & 100.0 & & \\
\hline
\end{tabular}

The above table shows the results about the statement «VAT encourages people to save more money to avoid paying taxes». In the response of it the respondents have shown negative result as majority of them do not believe that forceful save of money could bring any prosperity in their lives. However, some also believe that this idea would work for the economic rebuilt.

Table 8

\section{At what extent do you agree that for an in-debt nation VAT might pose short term negative but long-term positive impact on its economy?}

\begin{tabular}{|l|l|c|c|c|c|}
\hline & & Frequency & Percent & Valid Percent & $\begin{array}{c}\text { Cumulative } \\
\text { Percent }\end{array}$ \\
\hline Valid & $\begin{array}{l}\text { Strongly } \\
\text { Disagree }\end{array}$ & 7 & 9.6 & 10.0 & 10.0 \\
\hline & Disagree & 14 & 19.2 & 20.0 & 30.0 \\
\hline & Neutral & 17 & 23.3 & 24.3 & 54.3 \\
\hline & Agree & 18 & 24.7 & 25.7 & 80.0 \\
\hline & $\begin{array}{l}\text { Strongly } \\
\text { Agree }\end{array}$ & 14 & 19.2 & 20.0 & 100.0 \\
\hline & Total & 70 & 95.9 & 100.0 & \\
\hline Missing & System & 3 & 4.1 & & \\
\hline
\end{tabular}


The above table shows about the impact of in-debt nation VAT on the economy. The majority of respondents in the favor of this in-debt nation VAT policy that has long-term positive impact on the economy. However, some respondents show neutral behavior whereas other respondents do not agree with in-debt nation VAT which has positive impact on the economy.

Table 9

Consumer spending has decreased in the after-math VAT implementation?

\begin{tabular}{|l|l|c|c|c|c|}
\hline & & Frequency & Percent & Valid Percent & $\begin{array}{c}\text { Cumulative } \\
\text { Percent }\end{array}$ \\
\hline Valid & $\begin{array}{l}\text { Strongly } \\
\text { Disagree }\end{array}$ & 22 & 30.1 & 31.4 & 31.4 \\
\hline & Disagree & 18 & 24.7 & 25.7 & 57.1 \\
\hline & Neutral & 16 & 21.9 & 22.9 & 80.0 \\
\hline & Agree & 10 & 13.7 & 14.3 & 94.3 \\
\hline & $\begin{array}{l}\text { Strongly } \\
\text { Agree }\end{array}$ & 4 & 5.5 & 5.7 & 100.0 \\
\hline & Total & 70 & 95.9 & 100.0 & \\
\hline Missing & System & 3 & 4.1 & & \\
\hline Total & & 73 & 100.0 & & \\
\hline
\end{tabular}

The above table shows that the behavior of spending after the implementation of math VAT. According to respondent majority are disagree with that after the implementation of math VAT the spending behavior of consumers is decreased. However, few respondents are agreed with that the spending behavior of customers is decreased after math VAT implementation.

Table 10

Do you agree that implementing VAT significantly decrease SME's production?

\begin{tabular}{|l|l|c|c|c|c|}
\hline & & Frequency & Percent & Valid Percent & $\begin{array}{l}\text { Cumulative } \\
\text { Percent }\end{array}$ \\
\hline Valid & $\begin{array}{l}\text { Strongly } \\
\text { Disagree }\end{array}$ & 9 & 12.3 & 12.9 & 12.9 \\
\hline & Disagree & 13 & 17.8 & 18.6 & 31.4 \\
\hline & Neutral & 12 & 16.4 & 17.1 & 48.6 \\
\hline & Agree & 26 & 35.6 & 37.1 & 85.7 \\
\hline & $\begin{array}{l}\text { Strongly } \\
\text { Agree }\end{array}$ & 10 & 13.7 & 14.3 & 100.0 \\
\hline & Total & 70 & 95.9 & 100.0 & \\
\hline Missing & System & 3 & 4.1 & & \\
\hline Total & & 73 & 100.0 & & \\
\hline
\end{tabular}


The above data shows the response about production of SME's which is reduced after the implementation of VAT. The majority of respondents agree with the statement as production of SME is reduced after VAT. However, other respondents are disagreed with the significant impact of VAT on the production of SME's.

Table 11

Implementation of VAT has increased inflation rate that reflects negative impact on Economy.?

\begin{tabular}{|l|l|c|c|c|c|}
\hline & & Frequency & Percent & Valid Percent & $\begin{array}{c}\text { Cumulative } \\
\text { Percent }\end{array}$ \\
\hline Valid & $\begin{array}{l}\text { Strongly } \\
\text { Disagree }\end{array}$ & 4 & 5.5 & 5.7 & 5.7 \\
\hline & Disagree & 6 & 8.2 & 8.6 & 14.3 \\
\hline & Neutral & 16 & 21.9 & 22.9 & 37.1 \\
\hline & Agree & 28 & 38.4 & 40.0 & 77.1 \\
\hline & $\begin{array}{l}\text { Strongly } \\
\text { Agree }\end{array}$ & 16 & 21.9 & 22.9 & 100.0 \\
\hline & Total & 70 & 95.9 & 100.0 & \\
\hline Missing & System & 3 & 4.1 & & \\
\hline Total & & 73 & 100.0 & & \\
\hline
\end{tabular}

The above table depicts the numerical data about the significant role of VAT that has negative impact on the economy. The majority of respondents agree that inflation rate is high with the implementation of VAT that decreased the economy. However, some respondents show neutral behavior as they have no idea about impact of VAT on their economy.

Table 12

Do you agree with the idea of Bahrain's government to implement VAT with an aim to increase revenue to support national economy?

\begin{tabular}{|l|l|c|c|c|c|}
\hline & & Frequency & Percent & Valid Percent & $\begin{array}{c}\text { Cumulative } \\
\text { Percent }\end{array}$ \\
\hline Valid & $\begin{array}{l}\text { Strongly } \\
\text { Disagree }\end{array}$ & 20 & 27.4 & 28.6 & 28.6 \\
\hline & Disagree & 11 & 15.1 & 15.7 & 44.3 \\
\hline & Neutral & 20 & 27.4 & 28.6 & 72.9 \\
\hline & Agree & 15 & 20.5 & 21.4 & 94.3 \\
\hline & $\begin{array}{l}\text { Strongly } \\
\text { Agree }\end{array}$ & 4 & 5.5 & 5.7 & 100.0 \\
\hline & Total & 70 & 95.9 & 100.0 & \\
\hline Missing & System & 3 & 4.1 & & \\
\hline
\end{tabular}

The above-mentioned table depicts about the implementation of VAT by government that support national economy of Bahrain and generate large revenue. The majority of respondents disagree with the implementation of VAT and its positivity 
because they have idea that VAT disturb the economy of Bahrain. Therefore, some are agreed with the implementation of VAT which enhanced the economy of nation as generating large revenue.

Table 13

Do you think that due to the increase in VAT, the revenue might increase but foreign investment will reduce that can pose negative impact on the economy as foreign investment is a major part of Bahrain GDP?

\begin{tabular}{|l|l|c|c|c|c|}
\hline & & Frequency & Percent & Valid Percent & $\begin{array}{c}\text { Cumulative } \\
\text { Percent }\end{array}$ \\
\hline Valid & $\begin{array}{l}\text { Strongly } \\
\text { Disagree }\end{array}$ & 6 & 8.2 & 8.6 & 8.6 \\
\hline & Disagree & 4 & 5.5 & 5.7 & 14.3 \\
\hline & Neutral & 10 & 13.7 & 14.3 & 28.6 \\
\hline & Agree & 28 & 38.4 & 40.0 & 68.6 \\
\hline & $\begin{array}{l}\text { Strongly } \\
\text { Agree }\end{array}$ & 22 & 30.1 & 31.4 & 100.0 \\
\hline & Total & 70 & 95.9 & 100.0 & \\
\hline Missing & System & 3 & 4.1 & & \\
\hline Total & & 73 & 100.0 & & \\
\hline
\end{tabular}

In the above table, data depicts the response of respondents regarding to the VAT that increased the large revenue at national level but reduced the economy in foreign investment as the GDP of Bahrain is disturbed. However, the majority of respondents show that the implementation of VAT reduced the foreign investment that has negative impact on the GDP of Bahrain. Some respondents show neutral behavior.

Table 14

At what level do you agreed that VAT would grow Bahrain's revenues by up to $2 \%$ of the country's GDP?

\begin{tabular}{|l|l|c|c|c|c|}
\hline & & Frequency & Percent & Valid Percent & $\begin{array}{c}\text { Cumulative } \\
\text { Percent }\end{array}$ \\
\hline Valid & $\begin{array}{l}\text { Strongly } \\
\text { Disagree }\end{array}$ & 26 & 35.6 & 37.1 & 37.1 \\
\hline & Disagree & 17 & 23.3 & 24.3 & 61.4 \\
\hline & Neutral & 20 & 27.4 & 28.6 & 90.0 \\
\hline & Agree & 6 & 8.2 & 8.6 & 98.6 \\
\hline & $\begin{array}{l}\text { Strongly } \\
\text { Agree }\end{array}$ & 1 & 1.4 & 1.4 & 100.0 \\
\hline & Total & 70 & 95.9 & 100.0 & \\
\hline Missing & System & 3 & 4.1 & & \\
\hline Total & & 73 & 100.0 & & \\
\hline
\end{tabular}


The data of above-mentioned table depicts about the implementation of VAT that enhanced the revenue as well as country's GDP. According to the respondent's majority are disagree with the positive role of VAT that would enhance the growth of Bahrain's economy more than $2 \%$ of GDP

\section{Regression analysis}

Table 15

\section{Regression Analysis}

ANOVA $^{\mathrm{a}}$

\begin{tabular}{|r|c|c|c|c|c|}
\hline \multicolumn{1}{|c|}{ Model } & $\begin{array}{c}\text { Sum of } \\
\text { Squares }\end{array}$ & Df & Mean Square & F & Sig. \\
\hline 1 Regression & 2.326 & 1 & 2.326 & 2.095 & $.152^{\mathrm{b}}$ \\
\hline Residual & 75.516 & 68 & 1.111 & & \\
\hline Total & 77.843 & 69 & & & \\
\hline
\end{tabular}

Table 16

\section{Coefficients $^{\mathrm{a}}$}

\begin{tabular}{|c|c|c|c|c|c|}
\hline & \multicolumn{2}{|c|}{ Unstandardized Coefficients } & $\begin{array}{c}\text { Standardized } \\
\text { Coefficients }\end{array}$ & & \\
\hline Model & $\mathbf{B}$ & Std. Error & Beta & T & Sig. \\
\hline (Constant) & 1.682 & .333 & & 5.045 & .000 \\
\hline & .155 & .107 & .173 & 1.447 & .152 \\
\hline
\end{tabular}

In the above table, I tis found that the beta values are 1.682 and .155 between the actual and expected ratio whereas the significance value is .000 which shows that the relationship between the variables is significant.

Pearson's Correlation

\section{Correlations}

\begin{tabular}{|l|l|c|c|}
\hline & & VAT. & SMS's Production \\
\hline VAT & Pearson Correlation & 1 & .200 \\
\hline & Sig. (2-tailed) & & .097 \\
\hline & $\mathrm{N}$ & 70 & 70 \\
\hline $\begin{array}{l}\text { SMS's Production } \\
\text { decrease }\end{array}$ & Pearson Correlation & .200 & 1 \\
\hline & Sig. (2-tailed) & .097 & $\mathbf{7 0}$ \\
\hline & $\mathbf{N}$ & $\mathbf{7 0}$ & \\
\hline
\end{tabular}

The correlation test is performed to evaluate the relationship between the two variables i.e. VAT and SMEs production in which it is found that there is positive 
relationship between the two variables with Pearson correlation value .200 which means that when VAT increases then it would decrease the production of the business.

Table 18

\section{Reliability Scale Analysis}

\begin{tabular}{|c|c|}
\hline Cronbach's Alpha & N of Items \\
\hline .712 & 10 \\
\hline
\end{tabular}

The above table shows the reliability scale test results which is used to check the consistency of the research. In this test the results show the Cronbach's Alpha value as .712 which shows that the research has good consistency and the research results are acceptable.

From the results of the research it is found that people have mixed response towards the role of VAT in economic development. Some of the respondents believe that VAT has increased burden on the economy by reducing the production of the business organizations as well as by it has caused decrease in the foreign investment. On the other hand, it is also found that the collection of the revenue through the VAT is expected to contribute $2 \%$ in the GDP of the country. Overall, there are mixed expectation of the respondents regarding the role of VAT in the economic development of the country.

\section{Conclusion and Recommendations}

\section{Conclusion}

Value added tax is a technique use by the government to earn revenue to support the economy of the country. The VAT is also known as consumption tax which is required by the consumers on the consumption of some services or goods. The governments all over the world have been using this technique in which the consumers directly participate in supporting the economy. The VAT was introduced in UK in 1973 whereas recently, Bahrain has implemented 5\% VAT from the of the year 2019. Bahrain had been zero tax country but the debt of the country increased to alarming situation and reached to BHD 11.5 billion that raised major economic issues for the country. Subsequently, to tackle this economic situation, the government of Bahrain has decided to impose 5\% which has been implicated since 2019. The government is expecting that it would be a great idea to support lingering economy of the country whereas on the other hand, the locals as well as the SMEs and MNCs have recorded serious protest against this act of the government.

From the research, it is found that the implementation of VAT has posed multifaceted facts on the economy of Bahrain. On one side, it is exposed that the inflation rate has increased in the aftermath of the implementation of VAT. It is also 
found that the production especially of SMEs has greatly reduced that pose negative impact on the economy of the country because due to the reduce in the production the profit margin of the companies has reduced two ways such as in terms of taxation as well as in term of reduced business that pose negative impact on the economy. Following this, there is another major concern associated with the economic suffering of Bahrain under the influence of VAT implementation such as it is found from the research that in aftermath of VAT, the foreign investment has also reduced at great extent that posed new economic challenges. Foreign investment contributed huge in the economy of Bahrain therefore, decrease in the foreign investment might pose new challenges. Furthermore, the individuals have also received its influence as the increasing inflation rate has reduced consumer's buying power that cause reduces of capital in market circulation.

On the other hand, it is also found that the Vat that seems a huge burden on the economy at the initial stage would produce better result by reducing the debt of the country that has reached to alarming scale. According to the research, the positive long term impact of the VAT is found as it is expected that from the first years the VAT collection would help to contribute $2 \%$ of the GDP of the country that is a good sign. Moreover, it is concluded that in short term VAT seems as an inflation bomb on the public and business sector but in long terms it is focused on to bring prosperity to the country.

\section{Recommendation}

From the research, it is found that by addressing the current situation of the country the idea of VAT implementation is a good step by the government but at the same time, there is need to create awareness among the people about the VAT and its expected long term impact on the economy of Bahrain;

1. There is need to create awareness among the people of Bahrain about the goals behind the implementation of VAT.

2. The government should give compulsion to the SMEs and other individuals that are living below the poverty line.

3. VAT performance should be monitored timely to ensure whether government is achieving its goals or not.

\section{REFERENCES}

1. Acheson, J., Deli, Y., Morgenroth, E. L., Lambert, D., \& Murphy, M. (2018). VAT revenue elasticities: An analytical approach (No. 596). ESRI Working Paper. Source: https://www.econstor.eu/bitstream/10419/193933/1/WP596.pdf

2. Alavuotunki, K., Haapanen, M., \& Pirttilä, J. (2017). The consequences of the value-added tax on inequality. Source: https://www.econstor.eu/bitstream/10419/ 155560/1/cesifo1_wp6318.pdf 
3. Almajdoub, S. (2018). The Structural Constraints of Entrepreneurship in Bahrain. Issue Brief, 7. Source: https://scholarship.rice.edu/bitstream/handle/1911/ 102781/bi-brief-071718-cme-carnegie-london2_CWLE1xw.pdf?sequence $=1$

4. Baunsgaard, T., \& Keen, M. (2010). Tax revenue and (or?) trade liberalization. Journal of Public Economics,94(9-10), 563-577. Source: https://www.sciencedirect.com/science/article/abs/pii/S0047272709001479

5. Chan, S. G., \& Ramly, Z. (2018).The role of country governance on valueadded tax and inequality. Economics and Management. Source: https://dspace.tul.cz/ handle $/ 15240 / 124747$

6. Gunter, S., Riera-Crichton, D., Vegh Gramont, C. A., \& Vuletin, G. J. (2019). Policy Implications of Non-Linear Effects of Tax Changes on Output. Source: https://openknowledge.worldbank.org/bitstream/handle/10986/31188/WPS8720.pdf?s equence $=1$

7. Keen, M., \& Lockwood, B. (2010). The value added tax: Its causes and consequences. Journal of Development Economics, 92(2), 138-151. Sources: https://www.sciencedirect.com/science/article/pii/S0304387809000133

8. Kreishan, F. M., Elseoud, M. S. A., \& Selim, M. (2018). Oil Revenue and State Budget Dynamic Relationship: Evidence from Bahrain. International Journal of Energy Economics and Policy, 8(6), 174-179. Source: http://econjournals.com/index. php/ijeep/article/view/6991

9. Mao, C. W., \& Wu, W. C. (2019). Does the government-mandated adoption of international financial reporting standards reduce income tax revenue? International Tax and Public Finance, 1-22. Sources: https://link.springer.com/article/ 10.1007/s10797-018-9495-2

10. Mears, P. (2016). UNITED ARAB EMIRATES 2018 VAT TAX: THE EFFECTS ON EXPATS IN COUNTRY. Source:https://www.researchgate.net/ profile/Paul_Mears3/publication/310385594_UAE_VAT_TAX_2018_The_Effects_On_ Expats_In_Country/links/582c576108ae004f74b5e509.pdf

11. Shayah, M. H., \& Sun, Z. (2019, January). Employment in the Gulf Cooperation Council (GCC) Countries-Current Issues and Future Trends. In 2nd International Conference on Social Science, Public Health and Education (SSPHE 2018). Atlantis Press. Source: https://www.atlantis-press.com/proceedings/ssphe$18 / 55911790$

12. Vittori, J. (2019). Bahrain's Fragility and Security Sector Procurement. Source: https://carnegieendowment.org/files/Vittori_Bahrain_final.pdf 